\title{
An Eco-friendly Green Synthesis of Tungsten Nanoparticles from Moringa oleifera Lam. and Their Pharmacological Studies
}

\author{
Moringa oleifera Lam'dan elde edilen Tungsten Nanopartiküllerinin Çevre Dostu Yeşil Sentezi ve Farmakolojik \\ Çalışmalar
}

\author{
Ashish Kumar Sharma ${ }^{1}$, Ajit Kumar Swami ${ }^{2}$, Dinesh Jangir ${ }^{3}$, Mukesh Saran ${ }^{4}$, Tarun Kumar Upadhyay ${ }^{5}$, Rakesh Kumar Prajapat ${ }^{5}$ \\ Deepak Sharma ${ }^{6}$, Manas Mathur ${ }^{5}$
}

\author{
${ }^{1}$ Department of Microbiology, Mewar University, Chittorgarh, Gangrar, Rajasthan-312901, India \\ ${ }^{2}$ Department of Nanobiotechnology, Seminal Applied Sciences Pvt. Ltd, Lal Kothi , Rajasthan, Jaipur- 302015, India \\ ${ }^{3}$ Department of Chemistry, University of Rajasthan, JLN Marg, Jaipur \\ ${ }^{4}$ Department of Physics, Manipal University Jaipur, Dehmi Kalan, Jaipur Rajasthan- 303007, India \\ ${ }^{5}$ School of Agriculture, Suresh Gyan Vihar University, Mahal Road, Jagatpura, Jaipur, India \\ ${ }^{6}$ School of Agriculture, JECRC University, Jaipur , India
}

\begin{abstract}
Integration of nanoscience in medicine leads to the development of biomedical products that helps the society in a faster and safer manner. In the present studies tungsten nanoparticles were synthesized by green route using aqueous extracts of Moringa oleifera. Characterization was done through UV, SEM, TEM, FT-IR and XRD. The synthesized nanoparticles were spherical in shape with an average size of $10 \mathrm{~nm}$. Various bioactive compounds present in aqueous extract of this plant were responsible for bio reduction of nanoparticles. Further these nanoparticles were tested for various biological activities. In antimicrobial activity, it was observed that potent activity was shown against Bacillus subtilis $(18 \mathrm{~mm})$ at $80 \mu \mathrm{g} / \mathrm{ml}$ while against fungus maximum activity was observed against Fusarium oxysporium $(20 \mathrm{~mm})$ at same dose. The platelet aggregation of nanoparticles was assayed by Prothrombin (PT) and Activated Partial Thromboplastin time (APTT). In PT assay maximum activity was observed at 100 $\mu \mathrm{g} / \mathrm{ml}(158 \mathrm{sec}$ ) and in APTT it was found at $60 \mu \mathrm{g} / \mathrm{ml}$ (120sec). Cytotoxicity was also studied by MTT assay against various cell lines. Against MCF-7 (Breast cancer cell line ) nanoparticles were active at $200 \mu \mathrm{g} / \mathrm{ml}$ while in $3 T 3$ (fibroblast cell line) they were potent at $500 \mu \mathrm{g} / \mathrm{ml}$. Result showed the biosynthesis of tungsten nanoparticles using aqueous extract of Moringa oleifera is a clean, inexpensive and safe method that is free from toxic substance and consequently does not have any side effects.
\end{abstract}

Key Words: Green synthesis; Moringa oleifera; Platelet aggregation; Cytotoxic Assay; Antimicrobial activity.

Received: 05.15.2020

Accepted: 11.11 .2020

\section{ÖZET}

\begin{abstract}
Nanobilimin tıbba entegrasyonu, topluma daha hızlı ve daha güvenli bir şekilde yardımcı olan biyomedikal ürünlerin geliştirilmesine yol açar. Mevcut çalışmalarda tungsten nanopartiküller, Moringa oleifera'nın sulu ekstraktları kullanılarak yeşil yolla sentezlendi. UV, SEM, TEM, FT-IR ve XRD ile karakterizasyon yapıldı. Sentezlenen nanopartiküller, ortalama $10 \mathrm{~nm}$ 'lik bir boyutla küresel şekle sahipti. Bu bitkinin sulu ekstraktında bulunan çeşitli biyoaktif bileşikler, nanopartiküllerin biyolojik olarak indirgenmesinden sorumluydu. Ayrıca bu nanopartiküller, çeşitli biyolojik aktiviteler için test edildi. Antimikrobiyal aktivitede, aynı dozda Fusarium oxysporium'a $(20 \mathrm{~mm})$ karşı funguslara karşı maksimum aktivite gözlenirken, 80 ug / ml'de Bacillus subtilis'e $(18 \mathrm{~mm})$ karşı güçlü aktivite gösterildi. Nanopartiküllerin trombosit agregasyonu, Protrombin (PT) ve Aktif Kısmi Tromboplastin zamanı (APTT) ile test edildi. PT testinde maksimum aktivite $100 \mathrm{ug} / \mathrm{ml}$ 'de (158 saniye) gözlemlendi ve APTT'de 60 ug / ml'de (120 saniye) bulundu. Sitotoksisite ayrıca çeşitli hücre hatlarına karşı MTT testi ile incelenmiştir. MCF-7'ye (Göğüs kanseri hücre çizgisi) karşı nanopartiküller 200 ug / ml'de aktifken, 3T3'te (fibroblast hücre çizgisi) 500 ug / ml'de kuvvetliydi. Sonuç, Moringa oleifera'nın sulu ekstraktı kullanılarak tungsten nanopartiküllerinin biyosentezinin toksik madde içermeyen temiz, ucuz ve güvenli bir yöntem olduğunu ve dolayısıyla herhangi bir yan etkisi olmadığını gösterdi.
\end{abstract}

Anahtar Sözcükler: Yeşil sentez; Moringa oleifera; Trombosit agregasyonu; Sitotoksik Deney; Antimikrobiyal etkinlik.

Geliş Tarihi: 15.05 .2020

Kabul Tarihi: 11.11 .2020

ORCID IDs: A.S.0000-0003-4923-9269, D.J. 0000-003-1281-0425, M.S.0000-0003-0571-8866, T.K.U. 0000-0002-2551-9779, R.K.P. 0000-0003-4756-3970, D.S. 0000-00033249-1409, M.M. 0000-0003-0970-6096

Address for Correspondence / Yazışma Adresi: Manas Mathur School of Agriculture, Suresh Gyan Vihar University, Mahal Road, Jagatpura, Jaipur, India E-mail: manas.mathur@mygyanvihar.com

CTelif Hakkı 2020 Gazi Üniversitesi Tıp Fakültesi - Makale metnine http://medicaljournal.gazi.edu.tr/ web adresinden ulaşılabilir. (C) Copyright 2020 by Gazi University Medical Faculty - Available on-line at web site http://medicaljournal.gazi.edu.tr/ doi:http://dx.doi.org/10.12996/gmj.2020.167 


\section{INTRODUCTION}

Nanotechnology is described as portents at nanometre scale which is generally stated in range of 1-100 $\mathrm{nm}$. It manipulates various substances at the atomic, molecular along with macromolecular level to innovate substances at nanometre scale, and systems that have unique features and functions. The ecofriendly approach by green route of synthesis of nanoparticles is easy, efficient, in comparison to chemically synthesised or through use of microbes. Plant extracts could be an alternative to conventional chemical routes for the synthesis of metallic nanomaterials in a clean, nontoxic and ecologically sound manner (1). The key advantages green synthesis rout is that they possess significant phytochemicals which helps in the reduction of tungsten ions. These phytochemicals include ketones, aldehydes, amides, terpenoves, flavones, which are directly related to the reduction of ion and the formation of tungsten nanoparticles.

Moringa oleifera Lam is categorized in Moringaceae family having 14 species among which $M$. oleifera is most commonly found. In India conventionally this plant is known by the name "Sahanjana". Its pods and leaves have rich source of biomolecules like it contain 2.5 and $6.7 \mathrm{~g}$ protein $/ 100 \mathrm{~g}$, respectively. The plant is also recommended in folk remedies for conjunctivitis, high blood pressure, abdominal, boils, cold, discomfort, tumors, relapsing fever, hysteria and skin diseases, etc. It also bears certain bioactivity, viz., anti-inflammatory, antiasthmatic, antioxidant and hepatoprotective, antitumor etc. Moringa oleifera is consumed in Asian diet since many decades as raw food source.

The characterization and coating of tungsten oxide nanofibers by electrospinning process and sol-gel technique has been recommended by many researchers (2). They initiated the potential importance of the nanofibers as a sensor material for gas detection. Ultrafine tungsten and tungsten oxide powders with determined particle size and structure had been processed by a reverse microemulsion-mediated protocol (3). The fascinating solicitations in different fields like electronics, illumination, catalysis and gas sensors has been reported.

Recently existence and banquet of antimicrobial resistance is a serious issue in both developing and developed nations and which can leads to global crisis (4). A stratagem for the repression of resistance needs to be innovated, executed and evaluated which should be focused on improving rational use of antimicrobials and reducing prospects for spread of resistant organisms (5) - It has been reported (6) that, the metallic nanoparticles are meticulously being explored and broadly explored as potential antimicrobials. The antimicrobial potency of the nanoparticles is known to be a function of the surface area in communication with the microorganisms. Therefore, the search for new antimicrobial drugs from nanoparticles derived from natural sources has increased as a substitute to commercial drugs.

Arterial thrombosis swayed by aggregation of platelet are responsible for lifethreatening disorders like unstable angina and reocclusion after angioplasty. So adjournment of platelet aggregation is essential physiologically for prevention and treatment of cardiovascular diseases (7). During the initial stage of thrombosis, damage in blood vessels causes the production of adhesive proteins (such as collagen and von Willebrand factor) and soluble agonists (such as ADP and thrombin) at the injury site; which further leads to platelet adhesion, activation, and aggregation, therefore leads to formation of a platelet-rich thrombus (8).

It has been reported that synthesis of nanoparticles from biological sources is of keen interest due to synergistic properties valuated by such nanoparticles. Heparin (HP), when composited with nanomaterials, has been of keen interest for its chemical and biological features. HP has a number of therapeutic applications which can be elevated when composited with nanoparticles and has been recommended in various biological applications (9).

Biologically cancer is an undifferentiated growth of mass of cells bearing uncontrolled cell division (10) which is a major serious issue globally (11). So there is urge need for anticancer therapy (12). The fight against cancer is difficult particularly in the development of therapies for severely multiplying tumors. Chemotherapy is available for treatment of cancer but still it has low specificity and is limited by dose. It is a challenge to find the therapy and drugs for the treatments of various types of cancer. So, conventional process urge for the amalgamation of controlled released process and targeted drug delivery which is more effective and less harmful. Nanomaterials are being recommended at global level for cancer diagnosis and therapy (13).
Considering the importance of nanoparticle metal synthesis especially tungsten using different plants, the aim of this study was green synthesis of tungsten nanoparticles using aqueous extract of $M$. oleifera and investigation of its antimicrobial, antioxidant, antiplatelet, cytotoxicity and anti-tuberculosis activity.

\section{MATERIALS and METHODS}

The chemicals used for the synthesis of tungsten nanoparticles are tungsten oxide $\mathrm{WO}_{3}$ which was purchased from Hi-media, Jaipur, India. Doubly distilled water was used for the preparation of aqueous extracts. In vitro assay reagents for antimicrobial, antiplatelet and anticancer activity were purchased from Sigma Aldrich, India.

\section{Synthesis of Tungsten nanoparticles}

The synthesis of nanoparticles via green route particles were synthesised biologically by aqueous extract of Moringa oleifera. Initially leaves were washed properly with distilled water (14). $1 \mathrm{mM}$ of tungsten oxide was taken in $100 \mathrm{ml}$ autoclaved distilled water in a conical flask and kept on magnetic stirrer. $50 \mathrm{gm}$ leaves were weighed and grinded properly in the mortar and pestle for 15 to 20 minutes in distilled water. These grinded leaves were centrifuged at 4 으, 10000 rpm for 5 minutes. After the centrifugation the supernatant was collected and added to the flask containing the solution of tungsten oxide. It was kept overnight and the change in the colour of the solution from light brown to dark brown was observed which indicates the reduction and synthesis of tungsten nanoparticles.

\section{Characterisation}

Synthesised nanoparticles were characterised using various techniques viz, UV, SEM, TEM, FT-IR and XRD and further tested for their biological assays.

\section{Antimicrobial activity}

Antimicrobial activity of the synthesised nanoparticles was investigated by agar well diffusion method $(15,16,17)$ and activity index was calculated as:

\section{ACTIVITY INDEX $=$ Zone of inhibition of sample} Zone of inhibition of standard

Antiplatelet Activity

Blood samples were collected from KCJ Diagnostic center, near SMS Medical College, Jaipur and subjected to centrifugation. Centrifugation at $10000 \mathrm{rpm}$ for $5.5 \mathrm{~min}, 0.2 \mathrm{ml}$ platelet rich plasma was separated from the sample, dissolved in isotonic $\mathrm{CaCl}_{2}$. Different hemostatic constraints viz. Prothrombin time (PT) and Activated partial thromboplastin time (APTT) were investigated using protocol of Perkin (18).

\section{Cytotoxic assay}

MCF-7 cells are widely used cell lines in human breast cancer. They are derived from a pleural effusion of a malignant breast cancer and having estrogen and progesterone receptors. The human breast cancer cell line, Michigan Cancer Foundation-7 (MCF-7) and fibroblast cell line 3T3 was received from National Centre for Cell Science at Pune. The cell lines feeded in $10 \%$ fetal bovine serum (FBS) accomplished with Eagle minimum essential medium. Further they were maintained with laboratory conditions with $95 \%$ air and $100 \%$ relative humidity at $37^{\circ} \mathrm{C}$ in $5 \% \mathrm{CO}_{2}$. The viable cells noted down using a hemocytometer and diluted with medium having $5 \%$ FBS to give cell count of $1 \times 10^{5}$ cells $/ \mathrm{mL}$. The cytotoxicity evaluation of Moringa oleifera extract stabilized tungsten nanoparticles was performed using tetrazolium dye MTT assay as described by (19). About $1 \times 10^{5} \mathrm{~mL}^{-1}$ cells of MCF-7 and $3 T 3$ cell lines in their experimental growth phase was seeded in a flat bottomed 96 well polystyrene coated plate and incubated for cell attachment.

\section{Statistical analysis}

All the quantitative experiments were carried out in replicates, mean and standard deviation were calculated and results are expressed as mean \pm standard deviation. 


\section{RESULTS}

\section{Green synthesis of Tungsten nanoparticles}

The Moringa oleifera plant extract was employed for the green synthesis of tungsten nanoparticles using established protocols.

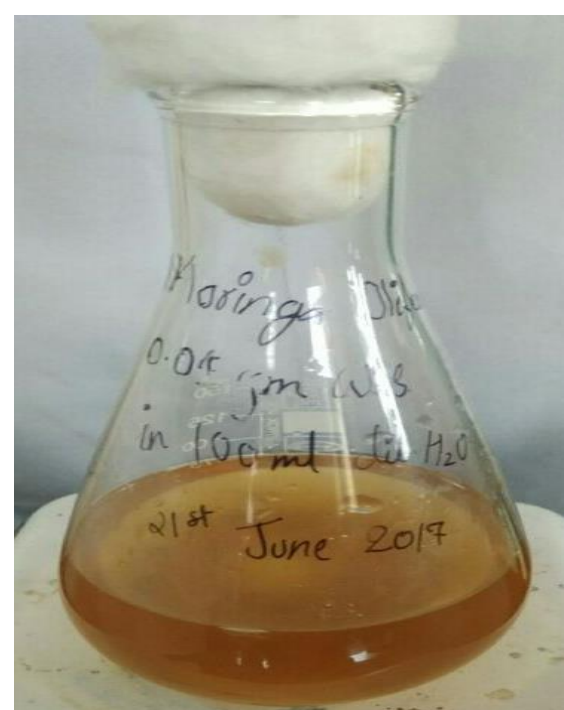

Before

Figure 1. Change in colour showing reduction of Tungsten nanoparticles

\section{Characterization of synthesised nanoparticles}

\section{Ultraviolet-visible spectroscopy}

Formation of nanoparticles is generally determined by optical properties which is one of the main criteria for their synthesis. Free electrons in the these nanoparticles educed by gripping visible light and transmitted to a higher energy level but the electron is unstable in an excited state and returns to the base energy level and as a result a photon is emitted. Simultaneously resonance frequency of surface plasmon in the metallic nanoparticles depends on shape, size and environment maintained during synthesis of nanoparticles. The UV-Vis spectrum of tungsten nanoparticles gave absorbance peaks around $400 \mathrm{~nm}$ and it showed strong resonance at this wavelength. The UV-vis spectra also revealed that these nanoparticles remained stable even after $24 \mathrm{~h}$ and it further confirms the biosynthesis of nanoparticles. (Fig. 2)

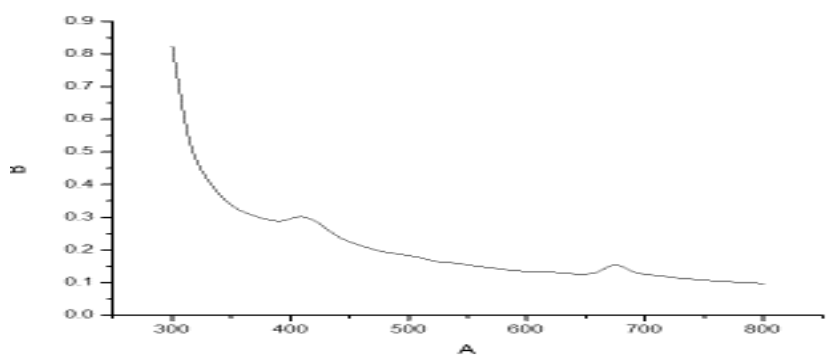

Figure 2 UV spectra of synthesised tungsten nanoparticles

\section{SEM and TEM}

SEM was applied to study surface morphology and the topography of synthesized nanoparticles. The size of nanoparticles varied from 10 to $20 \mathrm{~nm}$. It was observed that the biosynthesized nanoparticles were mostly spherical in shape. The shape and size of the nanoparticles were further studied by TEM. It was observed that synthesized nanoparticles were well dispersed, with an average size of $10 \mathrm{~nm}$. The data from TEM image were in a good agreement with the SEM. (Fig. 3 and 4).
After the addition of the plant leaf extract to solution of tungsten oxide it was observed that the colour of the reaction mixture was gradually changed from light yellow to dark brown, indicating the synthesis of nanoparticles (Fig.1). 
FT-IR

FTIR was applied in order to investigate possible biomolecules bearing different functional groups responsible for reduction, capping and efficient stabilization of newly synthesized nanoparticles (Fig. 5). The absorption bands at 3340, 2948, 2821, 2042, 1662, 1459, 1402, 1314, 1108 and $949 \mathrm{~cm}^{-1}$ were observed. The strong peaks at $3340 \mathrm{~cm}^{-1}$ correspondes to Hydroxy group, $\mathrm{H}$-bonded $\mathrm{OH}$ stretches. The band at $2948 \mathrm{~cm}^{-1}$ was attributed to methyl $\mathrm{CH}$ asym./sym stretches. The peak at $2821 \mathrm{~cm}^{-1}$ correspondes to methylamino, $\mathrm{N}-\mathrm{CH}_{3}$ and $\mathrm{C}-\mathrm{H}$ stretches.

The band at $2042 \mathrm{~cm}^{-1}$ corresponds to transition metal carbonyl, while band at $1662 \mathrm{~cm}^{-1}$ corresponds to alkenyl C-C stretch, band at 1459 shows presence of methylene $\mathrm{C}-\mathrm{H}$ bends. Band at $1402 \mathrm{~cm}^{-1}$ corresponds to phenol or tertiary alcohol, $\mathrm{OH}$ which is also represented by bands at $1314 \mathrm{~cm}^{-1}$ while $1108 \mathrm{~cm}^{-1}$ represents secondary alcohol having $\mathrm{C}-\mathrm{O}$ stretches and $949 \mathrm{~cm}^{-1}$ represents $\mathrm{C}-\mathrm{H}$ out of plane bend. These different phytochemicals were responsible for biosynthesis of tungsten nanoparticles.

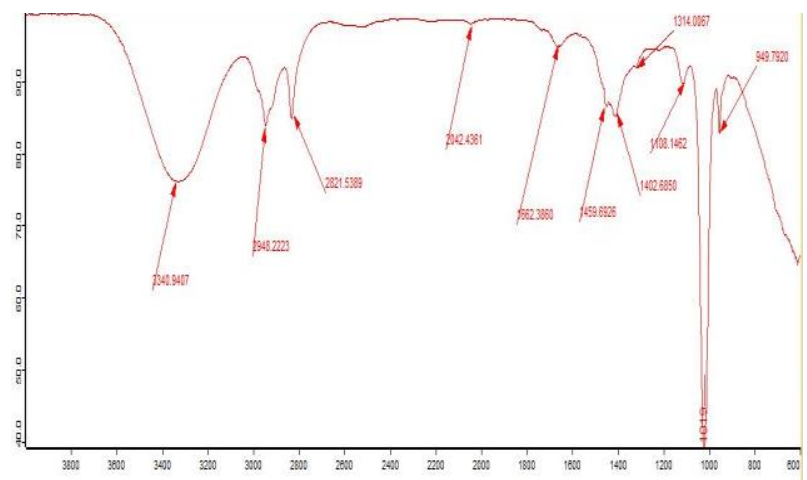

Figure 5 FT-IR spectra showing presence of different functional groups engaged in synthesis of nanoparticles

\section{XRD}

X-ray diffraction (XRD) studies were carried out to confirm the synthesis of WNPs and characterize crystallinity and the phase pattern of synthesize tungsten nanoparticles.

It was observed that $2 \theta$ (in degrees) were in the range of 28.4 to $66.5^{\circ} \mathrm{C} \mathrm{(Fig.} \mathrm{6).}$ The said $2 \vartheta$ values of peaks were in accordance with the standard of JCPDS. The XRD study confirms that the resultant particles were nanoparticles. Furthermore, it also confirms that the synthesized nanoparticles were free of impurities as no other characteristics XRD peaks were observed. The mean grain crystalline size of green synthesized tungsten nanoparticles was calculated using the DebyeScherrer formula

\section{$D=K \lambda$}

\section{$8 \cos \theta$}

where $D$ is the average crystalline diameter size $(\AA), K$ is a constant $(0.9), \lambda$ is the wavelength of the X-ray used ( $k=1.54 \AA$ ), ' $B$ ' is the angular line width at the half maximum of diffraction (radians) and ' $\Theta$ ' is the Bragg's angle (degrees) (20).

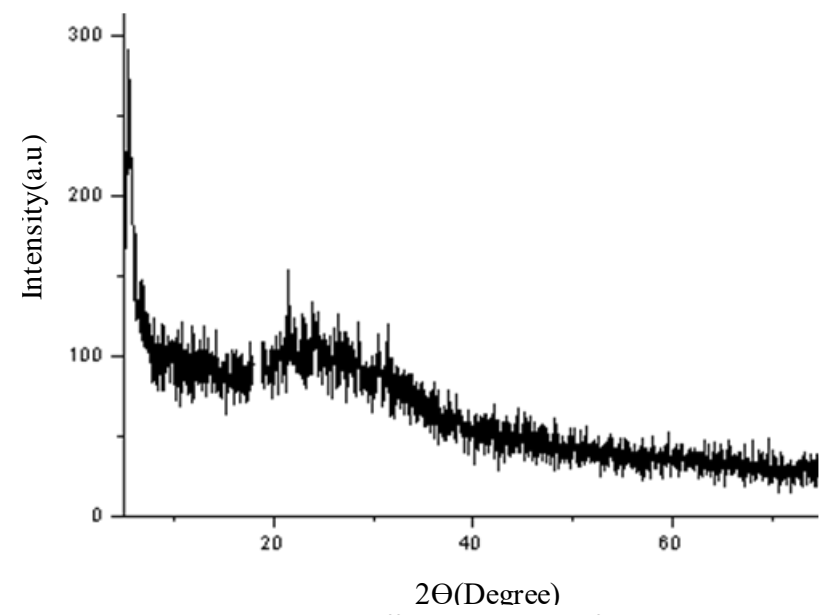

Figure 6 XRD spectra showing diffraction pattern of synthesized nanoparticles.

Antimicrobial activity

The reduced nanoparticles showed potent antibacterial and antifungal activity at concentration ranging from $20 \mu \mathrm{g} / \mathrm{ml}$ to $80 \mu \mathrm{g} / \mathrm{ml}$ on various clinical isolates. It was observed that against $E$. coli maximum zone was observed at $80 \mu \mathrm{g} / \mathrm{ml}(14 \mathrm{~mm})$. Against Bacillus subtilis maximum zone was observed at $80 \mu \mathrm{g} / \mathrm{ml}(18 \mathrm{~mm})$ which was highest among all tested sample. When nanoparticles were tested against Pseudomonas aeruginosa it was observed that no activity was observed at 40 and $60 \mu \mathrm{g} / \mathrm{ml}$ while maximum activity was observed at $80 \mu \mathrm{g} / \mathrm{ml}$ $(14 \mathrm{~mm})$ which was at par with E. coli. Against Streptomyces grisveus maximum zone was observed at $80 \mu \mathrm{g} / \mathrm{ml}(16 \mathrm{~mm}$ ) (Table 1)

In antifungal activity maximum activity was observed at $80 \mu \mathrm{g} / \mathrm{ml}$ $(20 \mathrm{~mm})$ against Fusarium oxysporum. Against Penicillium funiculosum activity was observed at only 60 and $80 \mu \mathrm{g} / \mathrm{ml}(14$ and $16 \mathrm{~mm}$ respectively). Against Candida albicans maximum activity was observed at $80 \mu \mathrm{g} / \mathrm{ml}(16 \mathrm{~mm})$ which was at par with that of Penicillium funiculosum. However Trichoderma reesei was found to be partial resistant (Table 2).

Table 1 Antibacterial activity of Tungsten Nanoparticle prepared by green synthesis route

\begin{tabular}{|c|c|c|c|c|}
\hline $\begin{array}{l}\text { Concentration } \\
\text { (in } \mu \mathrm{g} / \mathrm{ml} \text { ) }\end{array}$ & E.coli & Bacillus subtilis & $\begin{array}{l}\text { Pseudomonas } \\
\text { aeruginosa }\end{array}$ & Streptomyces grisveus \\
\hline \multirow[t]{2}{*}{20} & IZ-Nil & IZ-Nil & $\mathrm{IZ}-12 \pm 0.03$ & $I Z-8 \pm 0.009$ \\
\hline & Al- & Al- & Al-0.55 & Al-0.33 \\
\hline \multirow[t]{2}{*}{40} & $1 Z-6 \pm 0.008$ & IZ-13 \pm 0.03 & IZ-Nil & IZ-Nil \\
\hline & $\mathrm{Al}-0.27$ & Al-0.59 & Al- & Al- \\
\hline \multirow[t]{2}{*}{60} & $1 Z-12 \pm 0.03$ & IZ-Nil & IZ-Nil & IZ-10 \pm 0.01 \\
\hline & Al-0.55 & $\mathrm{Al}-$ & $\mathrm{Al}-$ & Al-0.46 \\
\hline \multirow[t]{2}{*}{80} & IZ-14 \pm 0.04 & IZ-18 \pm 0.06 & $\mathrm{IZ}-14 \pm 0.04$ & IZ-16 \pm 0.06 \\
\hline & Al-0.63 & Al-0.81 & Al-0.63 & Al-0.72 \\
\hline Standard & IZ -22 & IZ -22 & IZ -22 & IZ -22 \\
\hline
\end{tabular}

* Ciprofloxacin (as Standard at 1mg/ml), IZ- Inhibition Zone (in mm) , Al- Activity index

(Values are mean of three replicates ) 


\begin{tabular}{|c|c|c|c|c|}
\hline $\begin{array}{l}\text { Concentration } \\
\text { (in } \mu \mathrm{g} / \mathrm{ml} \text { ) }\end{array}$ & Fusarium oxysporum & Penicillium funiculosum & Candida albicans & Trichoderma reesei \\
\hline \multirow[t]{2}{*}{20} & $\mathrm{IZ}-6 \pm 0.02$ & IZ-Nil & IZ-Nil & IZ-Nil \\
\hline & $\mathrm{Al}-0.3$ & $\mathrm{Al}-$ & Al- & Al- \\
\hline \multirow[t]{2}{*}{40} & $\mathrm{IZ}-14 \pm 0.04$ & IZ-Nil & $\mid Z-10 \pm 0.01$ & $\mathrm{IZ}-8 \pm 0.008$ \\
\hline & Al-0.7 & Al- & Al-0.5 & Al-0.4 \\
\hline \multirow[t]{2}{*}{60} & $\mathrm{IZ}-18 \pm 0.08$ & $I Z-14 \pm 0.04$ & $I Z-14 \pm 0.04$ & $\mathrm{IZ}-10 \pm 0.01$ \\
\hline & Al-0.9 & $\mathrm{Al}-0.7$ & Al- 0.7 & Al- 0.5 \\
\hline \multirow[t]{2}{*}{80} & IZ $-20 \pm 0.1$ & $\mathrm{IZ}-16 \pm 0.06$ & $I Z-16 \pm 0.06$ & $\mathrm{IZ}-12 \pm 0.02$ \\
\hline & Al-1 & Al-0.8 & Al-0.8 & Al-0.6 \\
\hline Standard & IZ -20 & IZ -20 & IZ-20 & IZ -20 \\
\hline
\end{tabular}

*Ketokenazole (as Standard at 1mg/ml), IZ- Inhibition Zone , Al- Activity index

(Values are mean of three replicates )

Antiplatelet Activity

Prothrombin Time (PT)

All the concentrations of nanoparticles prolonged the clotting time as compared to control. Significant activity was observed at $100 \mu \mathrm{gmL}^{-1}(4.27$ times of control and 10.5 times as compared to standard), which was maximum and increased in linear fashion according to dose level (Table 3).

\section{Activated Partial thromboplastin time (APTT)}

In this assay significant activity was observed at $60 \mu \mathrm{gmL}^{-1}$ (2.55 times of control and 3 times as compared to standard), which increased slowly (Table 4) with increase in dose level.

Table 3 Antiplatelet activity of reduced Tungsten nanoparticles by Prothrombin time (PT)

\begin{tabular}{lllll}
\hline S.N & $\begin{array}{l}\text { Concentration of Sample } \\
\text { (in } \boldsymbol{\mu g} / \mathbf{m l})\end{array}$ & Time & a *Standard & b $^{*}$ Control \\
\hline 1 & 10 & $25 \mathrm{sec}$ & 1.66 & 0.67 \\
2 & 20 & $58 \mathrm{sec}$ & 3.86 & 1.56 \\
3 & 30 & $40 \mathrm{sec}$ & 2.66 & 1.08 \\
4 & 40 & $45 \mathrm{sec}$ & 3.0 & 1.21 \\
5 & 50 & $88 \mathrm{sec}$ & 5.86 & 2.37 \\
6 & 60 & $80 \mathrm{sec}$ & 5.33 & 2.16 \\
$\mathbf{7}$ & 70 & $85 \mathrm{sec}$ & 5.66 & 2.29 \\
8 & 80 & $102 \mathrm{sec}$ & 6.8 & 2.75 \\
9 & 90 & $135 \mathrm{sec}$ & 9.0 & 3.64 \\
10 & $\mathbf{1 0 0}$ & $\mathbf{1 5 8 ~ \mathbf { ~ s e c }}$ & $\mathbf{1 0 . 5}$ & $\mathbf{4 . 2 7}$ \\
\hline
\end{tabular}

Control $-37 \mathrm{~s}$.

Standard PT (plasma + PT reagent) $-15 \mathrm{~s}$

* Denotes potency of the sample at different concentrations when compared with standard and control

Table 4 Antiplatelet activity of reduced Tungsten nanoparticles by Activated Partial Thromboplastin time (APTT)

\begin{tabular}{|c|c|c|c|c|}
\hline S.N & $\begin{array}{l}\text { Concentration of Sample } \\
\text { (in } \mu \mathrm{g} / \mathrm{ml} \text { ) }\end{array}$ & Time & a *Standard & $\mathrm{b}^{*}$ Control \\
\hline 1 & 10 & $45 \mathrm{sec}$ & 1.12 & 0.95 \\
\hline 2 & 20 & $37 \mathrm{sec}$ & 0.92 & 0.78 \\
\hline 3 & 30 & $55 \mathrm{sec}$ & 1.37 & 1.17 \\
\hline 4 & 40 & $62 \mathrm{sec}$ & 1.55 & 1.31 \\
\hline 5 & 50 & $75 \mathrm{sec}$ & 1.87 & 1.59 \\
\hline 6 & 60 & $120 \mathrm{sec}$ & 3.0 & 2.55 \\
\hline 7 & 70 & $58 \mathrm{sec}$ & 1.45 & 1.48 \\
\hline 8 & 80 & $115 \mathrm{sec}$ & 2.55 & 1.70 \\
\hline 9 & 90 & $60 \mathrm{sec}$ & 1.33 & 1.27 \\
\hline 10 & 100 & $54 \mathrm{sec}$ & 1.35 & 1.14 \\
\hline
\end{tabular}

Control $-47 \mathrm{~s}$.

Standard PT (plasma + PT reagent) $-40 \mathrm{~s}$.

* Denotes Potency of the sample at different concentrations when compared with standard and control

Cytotoxic Assay

The present study revealed the anticancer and cytotoxic potential of nanoparticles on breast cancer cells MCF-7 and fibroblast cell line 3T3 and the report was compared with cisplastin at various concentrations. It was noticed that nanoparticles with a concentration ranging from 10 to $200 \mu \mathrm{g} / \mathrm{ml}$ resulted in dose dependent decrease in cellular viability of cancer cells with IC 50 value of $44.79 \mu \mathrm{g} / \mathrm{ml}$ while cisplastin treatment revealed IC 50 value of $9.47 \mu \mathrm{g} / \mathrm{ml}$.
The variation between the positive drug and samples is because the positive drug is a pure and so it will require lower concentration to inhibit the growth of cancer cells. Alternatively, higher concentration of samples resulted in more than $50 \%$ inhibition of cancer cells. Screening of cytotoxicity of nanoparticles on 3T3 cells revealed that it was marginally toxic to cells even at higher concentration. 
Overall in MCF-7, the viable cells were around $65 \%$ at $100 \mu \mathrm{g} / \mathrm{ml}$ which decreased to $47.20 \%$ which reveals the fact that it is toxic at increasing concentration of test sample. In $3 \mathrm{~T} 3$ cell lines, it was observed that the cells were viable at $61 \%$ at $500 \mu \mathrm{g} / \mathrm{ml}$ which proved its non-toxicity (Tables 6-8)

Table 6 Showing percent cell viability of standard (Cisplastin) (MCF7 breast cancer cell line)

\begin{tabular}{ll}
\hline Concentrations $(\mu \mathrm{g} / \mathrm{ml})$ & Viability \\
\hline $\mathbf{5}$ & $57.02 \pm 0.43$ \\
$\mathbf{1 0}$ & $52.12 \pm 0.34$ \\
$\mathbf{2 5}$ & $44.52 \pm 0.26$ \\
$\mathbf{5 0}$ & $41.09 \pm 0.33$ \\
$\mathbf{1 0 0}$ & $23.52 \pm 0.12$ \\
$\mathbf{2 5 0}$ & $19.36 \pm 0.7$ \\
$\mathbf{5 0 0}$ & $9.47 \pm 0.5$ \\
\hline
\end{tabular}

Table 7 Showing cell viability of tungsten nanoparticle against MCF7 breast cancer cell line.

\begin{tabular}{ll}
\hline Tested concentrations & Viability \\
\hline 10 & \\
25 & $92.49 \pm 0.65$ \\
50 & $85.21 \pm 0.58$ \\
100 & $78.59 \pm 0.44$ \\
200 & $65.42 \pm 0.37$ \\
Control & $44.79 \pm 0.43$ \\
\hline
\end{tabular}

Table 8 Percent cell viability of tungsten nanoparticle against $3 T 3$ fibroblast cell line

\begin{tabular}{ll}
\hline Tested concentrations $(\mu \mathrm{g} / \mathrm{ml})$ & Viability \\
\hline $\mathbf{2 5} \boldsymbol{\mu g}$ & \\
$\mathbf{5 0} \boldsymbol{\mu \mathrm { g }}$ & $94.39 \pm 0.88$ \\
$\mathbf{1 0 0} \boldsymbol{\mu \mathrm { g }}$ & $88.12 \pm 0.76$ \\
$\mathbf{2 5 0} \boldsymbol{\mu g}$ & $75.30 \pm 0.73$ \\
$\mathbf{5 0 0} \boldsymbol{\mu g}$ & $67.76 \pm 0.70$ \\
control & $61.29 \pm 0.65$ \\
\hline
\end{tabular}

\section{DISCUSSION}

Nanotechnology is increasing at rapid rate in biomedical sciences as innovative techniques which are being developed to investigate and manipulate the effect of single atoms and molecules against a wide range of living cells.

The current investigation presents a systematic and scientific approach to develop and investigate the nanoparticles and its biological activities against a range of routes. There is a great scope of the study of nanoparticles and as well as natural products in the present time as many therapeutic antimicrobial agents are widely prescribed though having limited effectiveness and further more overdosing is associated with many fatal side effects including generation of resistant mutants. Our approach is to evaluate the separate and synergistic antimicrobial activity of tungsten nanoparticles to improve the effectiveness of drug at low cost at pharmacologically safe concentration and its cardiovascular effect. Hence we concluded that reduced nanoparticles have good antimicrobial properties. We can also a that nanoparticles have potent antioxidant and antiplatelet activity. Cumulatively, they also bear potent anticancer and antituberclosis activity.

Physical methods for synthesis of nanoparticles needs large amount of energy and the chemical process possess some toxicity which is of non-use in biological applications. So attention has been focussed by many researchers for biosynthesis of nanoparticles by plants.

There are some earlier reports which proved that (21) anti-bacterial activity of the silver nanoparticles synthesized via green route has potency against Salmonella typhi, Pseudomonas aeruginosa, Staphylococcus aureus and Klebsiella spp. Further some researchers (22) reported that the silver nanoparticles had effect on antimicrobial and antifungal activity of new heterocycles. Synergic effects of the silver nanoparticles on the antimicrobial activity were reported by disk diffusion method. These silver nanoparticles possess potent activity against Aspergillus flavus which were observed in case of tungsten nanoparticles against selected microbes (23).

The strong antimicrobial effects in natural products synthesize by plants are very crucial as the resistance of many pathogens to antibiotics is one of the serious issues of medical science. Dependence on antibiotics result in raising the cost of health care due to prolonged treatment like admission and restoration, need to the making of new antibiotic agents and applying effective and widespread methods of infection control in order to prevent the spread of pathogens resistant to antibiotics. Some issues when consuming antibiotics is the occurrence of lethal and dangerous side effects such as hypersensitivity reactions, growth inhibition of hematopoietic stem cell, liver and kidney failure in some of patients. With the innovations of nanotechnology and production of plant based nanoparticles for their therapeutic applications, their use has increased dramatically in medical science.

Thus in the present research potent antimicrobial activity of synthesized tungsten nanoparticles were observed.There are several reports (24) on antiplatelet aggregation activities advocated for a new approach, which are recommended for the binding of drug receptors under a laboratory physiological environment. Further, growing appeal for innovations of natural anticoagulants is getting boon due to overwhelming consumer response requiring remedies devoid of undesirable side effects. Therefore, the inhibition of aggregation of platelet formation and anticoagulants using phytoceuticals and nutraceuticals can be promising approach for the prevention of thrombosis. Thus in the present investigation significant antiplatelet activity was observed in synthesised nanoparticles.

The cytotoxic potential of nanoparticles is correlated to physicochemical interface of tungsten atoms stabilized with functional groups of intracellular proteins, along with the nitrogen bases and phosphate groups in DNA. Some scanty reports proved that (25) the nanoparticles having anticancer potential possess ability to reduce expression of signalling proteins, like Akt and Ras, cytokine-based therapies, DNA- or protein based vaccines against particular tumor markers and tyrosine kinase inhibitors which are related to regular antitumor potential $(26,27)$.

Thus to best of our knowledge this is first comprehensive report on green synthesis of tungsten nanoparticle and their biological activities.

\section{Conflict of interest}

No conflict of interest was declared by the authors.

\section{Acknowledgement}

The authors are thankful to Heads, Mewar University and Seminal applied Sciences for providing the necessary facilities to carry out the research work related to the biological activities.

\section{REFERENCES}

1. Singh A , Gautam P K, Verma A, Singh V, Shivapriya P M, Shivalkar S, Sahoo A K, Samanta $\mathrm{S}$ K. Green synthesis of metallic nanoparticles as effective alternatives to treat antibiotics resistant bacterial infections: A review. Biotechnol Rep 2020; 25: e00427.

2. Muhammad I, Syed SAHR, Ylias S, Nunzio M, Tuquabo T, Prashant S. Template based sintering of WO3 nanoparticles into porous tungsten oxide nanofibers for acetone sensing applications, J Mater Chem C 2019; 7: 2961-70

3. Dargahi $M$, Masteri-Farahani $M$, Shahsavarifar S. et al. Microemulsion-mediated preparation of $\mathrm{Ce} 2(\mathrm{MoO} 4) 3$ nanoparticles for photocatalytic degradation of crystal violet in aqueous solution. Environ Sci Pollut Res 2020; 27: 12047-54. 
4. Singh A, Gaud B, Jaybhaye S. Optimization of synthesis parameters of silver nanoparticles and its antimicrobial activity. Mat Sci Ener Technol 2020; 3: 232- 36.

5. Sumathi S, Thomas A. Eco-friendly and antibacterial finishes of organic fabrics using herbal composite microencapsules. Int J Pharm Bio Sci 2017 ; 8(3): 310-321.

6. Moulahoum H, Zamani F G, Timur S, Zihnioglu F. Metal Binding Antimicrobial Peptides in Nanoparticle Bio-functionalization: New Heights in Drug Delivery and Therapy. Probiotics and antimicrobial proteins 2019; $12: 1-16$

7. Jin YR, Han XR , Zhang YH, Lee JJ, Lim Y, Chung JH. Antiplatelet activity of hesperetin, a bioflavonoid, is mainly mediated by inhibition of PLC- $\gamma 2$ phosphorylation and cyclooxygenase-1 activity. Atheroscl 2007; $194: 144-52$.

8. Rana A, Westein E, Niego B E, Hagemeyer C E. Shear-dependent platelet aggregation: mechanisms and therapeutic opportunities. Front Cardio Med 2019; $6: 141$

9. Khaliq N U, Sandra F C, Park D Y, Lee J Y, Oh K S, Kim D, Yuk S H. Doxorubicin/heparin composite nanoparticles for caspase-activated prodrug chemotherapy. Biomat 2016; 101: 131-42.

10. Kanchana A, Balakrishnan M. Anti-cancer effect of saponins isolated from Solanum trilobatum leaf extract and induction of apoptosis in human larynx cancer cell lines. Int J Pharm Sci 2011 ; 3: 356-64.

11. Devi JS, Bhimba BV. Silver nanoparticles: Antibacterial activity against wound isolates \& amp; in vitro cytotoxic activity on Human Caucasian colon adenocarcinoma. Asian Pac J Trop Dis 2012; 2 : 87-93.

12. Togashi $Y$, Shitara K, Nishikawa H. Regulatory $T$ cells in cancer immunosuppression implications for anticancer therapy. Nat Rev Clin Oncol 2019; 16(6): 356-71.

13. Rosarin FS, Arulmozhi V, Nagarajan S, Mirunalini S. Antiproliferative effect of silver nanoparticles synthesized using amla on Hep2 cell line. Asian Pac J Trop Med 2013; 6 : 110.

14. Saran M, Vyas S, Mathur M, Bagaria A. Green synthesis and characterisation of CuNPs: insights into their potential bioactivity. IET Nanobiotechnol 2018; 12(3):357-64.

15. Alizadeh Behbahani B, Shahidi F. Melissa officinalis essential oil: Chemical compositions, antioxidant potential, total phenolic content and antimicrobial activity. Nut Food Sci Res 2019; 6(1): 17-25
16. Malarkodi C, Annadurai G. A novel biological approach on extracellular synthesis and characterization of semiconductor zinc sulfide nanoparticles. Appl Nanosci $2013 ; 3$ : 38995.

17. Kumar K, Saran M, Yadav L, Shyamlal BR, Mathur M, Bagaria A, Chaudhary S. Efficient Antibacterial and Low Cytotoxic Potential of Silver Nanoparticles Produced Instantaneously Using Dimeric Gallate. ChemistrySelect 2018; 3(48): 13716-21.

18. Irfan M, Kim M, Rhee M H. Anti-platelet role of Korean ginseng and ginsenosides in cardiovascular diseases. J Gin Res 2020; 44(1): 24.

19. Van Meerloo J, Kaspers G J, Cloos J. Cell sensitivity assays: the MTT assay. In Cancer cell culture Humana Press 2011: pp. 237-45.

20. Allafchian AR, Majidian Z, lelbeigi $V$, Tabrizchi M. A novel method for the determination of three volatile organic compounds in exhaled breath by solid-phase microextraction-ion mobility spectrometry. Anal Bioanal Chem 2016; 408: 839-47.

21. Kalaiselvi M , Ramasamy S, Selvam M . 2013. Synthesis and characterization of silver nanoparticles from leaf extract of Parthenium hysterophorus and its anti-bacterial and antioxidant activity. Int J Curr Microbiol Appl Sci 2013; 2 : 220-27.

22. Kandile NG, Zaky HT, Mohamed MI, Mohamed HM . Silver Nanoparticles Effect on Antimicrobial and Antifungal Activity of New Heterocycles. Bull Kor Chem Soc $2010 ; 13$ : 3530-38.

23. Galli G . Structure, Stability and Electronic Properties of Nanodiamonds. Beyond Nanotubes; Colombo, L.; Fasolino, A., Eds.; Springer, 2010; pp 37-56.

24. Nie H, Meng L, Zhang H, Zhang J, Yin Z, Huang X. Analysis of anti-platelet aggregation components of Rhizoma Zingiberis using chicken thrombocyte extract and high performance liquid chromatography. Chin Med J 2008; $121: 1226-29$.

25. Sriram MI, Kanth SBM , Kalishwaralal K, Gurunathan S. Antitumor activity of silver nanoparticles in Dalton's lymphoma ascites model. Int J Nanomed 2010; 5 : 753-62.

26 Martins D, Frungillo L, Anazzetti MC, Melo PS , Durán N . Antitumoral activity of Lascorbic acid-poly- D,L-(lactide-co-glycolide) nanoparticles containing violacein. Int J Nanomed $2010 ; 5$ : 77-85.

27. Khan F, Pandey P, Ahmad V, | Tarun Kumar Upadhyay. Moringa oleifera methanolic leaves extract induces apoptosis and G0/G1 cell cycle arrest via downregulation of Hedgehog Signaling Pathway in human prostate PC-3 cancer cells. J Food Biochem 2020. doi.org/10.1111/jfbc.13338 